\title{
Avermectins, praziquantel and levamisole have in vitro efficacy against Neoechinorhynchus buttnerae (Neoechinorhynchidae) in Colossoma macropomum: A Serrasalmidae from the Amazon
}

\author{
Lígia C. D. Oliveira ${ }^{1}$ | Cláudia Majolo ${ }^{2}$ | Franmir R. Brandão ${ }^{3}$ | Caio Francisco S. Farias ${ }^{4}$ \\ Maria Inês B. Oliveira ${ }^{3}$ | Welliton B. Santos ${ }^{5}$ | Patrícia C. Monteiro ${ }^{3}$ | \\ Maria Juliete S. Rocha ${ }^{3}$ | Edsandra C. Chagas ${ }^{2,3}$ | Marcos Tavares-Dias ${ }^{1,6}$ (D) \\ ${ }^{1}$ Postgraduate Program on Tropical Biodiversity (PPGBio), Universidade Federal do Amapá (UNIFAP), Macapá, Brazil \\ ${ }^{2}$ Embrapa Amazônia Ocidental, Manaus, Brazil \\ ${ }^{3}$ Postgraduate Program on Fishery Sciences in the Tropics, Universidade Federal do Amazonas (UFAM), Manaus, Brazil \\ ${ }^{4}$ Uninorte Laureate International Universities, Manaus, Brazil \\ ${ }^{5}$ Universidade Nilton Lins, Manaus, Brazil \\ ${ }^{6}$ Embrapa Amapá, Macapá, Brazil \\ Correspondence \\ Marcos Tavares-Dias, Embrapa Amapá, Macapáp, Brazil. \\ Email: marcos.tavares@embrapa.br \\ Funding information \\ Conselho Nacional de Desenvolvimento Científico e Tecnológico, Grant/Award Number: 303013/2015-0
}

KEYWORDS: acanthocephalan, anthelminthics, infection, treatment

\section{1 | INTRODUCTION}

Neoechinorhynchus buttnerae Golvan, 1956 is an acanthocephalan of the family Neoechinorhynchidae for which the ostracod Cypridopsis vidua (Müller, 1776) Brady, 1867 is the intermediate host (Lourenço, Morey, Pereira, \& Malta, 2018). This endoparasite causes great problems in aquaculture production of Colossoma macropomum Cuvier, 1818 from the Brazilian Amazon, where it infects 100\% of the fish (Jerônimo et al., 2017; Lourenço, Morey, Pereira, \& Malta, 2017; Matos, Oliveira, Gomes, \& Silva, 2017), affecting the intestinal tissue of hosts and causing impairments of nutrient uptake (Matos et al., 2017) and leading to great economic losses of $100 \%$ of production (Silva-Gomes et al., 2017). However, this helminth endoparasite has been often neglected as causative agents of C. macropomum diseases. Therefore, as this acanthocephalan may have detrimental consequences for health of this farmed fish (Jerônimo et al., 2017; Lourenço et al., 2017; Matos et al., 2017), it is important to implement strategies to control them.

Anthelminthic drugs such as avermectins (ivermectin and emamectin benzoate) and benzimidazoles (albendazole, mebendazole and fenbendazole) have been used to treat parasitic infections by monogeneans, nematodes, digeneans and cestodes in different fish species (Collymore et al., 2014; Hardy-Smith et al., 2012; Shinn \& Bron, 2012). Despite continuing need to expand the use of strategies for integrated management of parasite control among farmed fish (Shinn \& Bron, 2012), treatment with anthelminthic drugs is a tool that has been little tested for controlling infections by acanthocephalan species. Levamisole, loperamide and praziquantel have been recommended for in vitro control of the acanthocephalans Neoechinorhynchus rutili Müller, 1780 and Echinorhynchus truttae Schrank, 1788 in Oncorhynchus mykiss Walbaum, 1792 (Taraschewski, Mehlhorn, \& Raether, 1990). Praziquantel has also shown potential as an oral treatment against the acanthocephalan Pomphorhynchus laevis Müller, 1776 in Barbus barbus Linnaeus, 1758 (Zuskova et al., 2018). The number of antiparasitic drugs that are efficacious, consistent and safe and which can be used across a wide range of environmental conditions is very limited. Since no other suitable chemotherapeutic treatments for acanthocephalan infections in fish are available, the aim of this study was to investigate the efficacy, in vitro, of albendazole, levamisole, fenbendazole, mebendazole, praziquantel, ivermectin, loperamide and emamectin benzoate against $N$. buttnerae in $C$. macropomum. 
TAB LE 1 Efficacy of different concentrations of the anthelminthics in Neoechinorhynchus buttnerae de Colossoma macropomum in different time of exposure

\begin{tabular}{|c|c|c|c|c|}
\hline Time & Control of DMSO (ml) & Live parasites & Dead parasites & $\mathrm{EC}_{50}(\mathrm{mg} / \mathrm{L})$ \\
\hline $6 \mathrm{hr}$ & 0.45 & 30 & 0 & \multirow[t]{2}{*}{-} \\
\hline $24 \mathrm{hr}$ & 0.45 & 29 & $0.3 \pm 0.5$ & \\
\hline Time & Control of Tween $80(\mathrm{ml})$ & Live parasites & Dead parasites & \\
\hline $6 \mathrm{hr}$ & 1.0 & 30 & 0 & \multirow[t]{2}{*}{-} \\
\hline $24 \mathrm{hr}$ & 1.0 & 30 & 0 & \\
\hline Time & $\begin{array}{l}\text { Control of distillated water } \\
(\mathrm{ml})\end{array}$ & Live parasites & Dead parasites & \\
\hline $6 \mathrm{hr}$ & 1.0 & 30 & 0 & \multirow[t]{2}{*}{-} \\
\hline $24 \mathrm{hr}$ & 1.0 & 28 & $0.7 \pm 1.1$ & \\
\hline Time & $\begin{array}{l}\text { Emamectin benzoate } \\
(\mathrm{mg} / \mathrm{L})\end{array}$ & Live parasites & Dead parasites & $\mathrm{EC}_{50}(\mathrm{mg} / \mathrm{L})$ \\
\hline \multirow[t]{9}{*}{$6 \mathrm{hr}$} & 12.5 & 30 & 0 & \multirow[t]{9}{*}{-} \\
\hline & 25.0 & 30 & 0 & \\
\hline & 50.0 & 30 & 0 & \\
\hline & 100 & 30 & 0 & \\
\hline & 200 & 26 & $1.3 \pm 0.6$ & \\
\hline & 300 & 30 & 0 & \\
\hline & 400 & 30 & 0 & \\
\hline & 500 & 30 & 0 & \\
\hline & 600 & 29 & $0.3 \pm 0.6$ & \\
\hline \multirow[t]{9}{*}{$24 \mathrm{hr}$} & 12.5 & 30 & 0 & \multirow[t]{9}{*}{61.8} \\
\hline & 25.0 & 25 & $1.7 \pm 0.6$ & \\
\hline & 50.0 & 26 & $1.3 \pm 1.1$ & \\
\hline & 100 & 1 & $9.7 \pm 0.6$ & \\
\hline & 200 & 0 & $10.0 \pm 0$ & \\
\hline & 300 & 1 & $9.7 \pm 0.6$ & \\
\hline & 400 & 1 & $9.7 \pm 0.6$ & \\
\hline & 500 & 4 & $8.7 \pm 1.5$ & \\
\hline & 600 & 1 & $9.7 \pm 0.6$ & \\
\hline Time & Ivermectin (mg/L) & Live parasites & Dead parasites & $\mathrm{EC}_{50}$ \\
\hline \multirow[t]{9}{*}{$6 \mathrm{hr}$} & 1,000 & 30 & 0 & \multirow[t]{9}{*}{-} \\
\hline & 1,500 & 30 & 0 & \\
\hline & 2,000 & 30 & 0 & \\
\hline & 2,500 & 30 & 0 & \\
\hline & 3,000 & 30 & 0 & \\
\hline & 3,500 & 30 & 0 & \\
\hline & 4,000 & 30 & 0 & \\
\hline & 4,500 & 30 & 0 & \\
\hline & 5,000 & 30 & 0 & \\
\hline
\end{tabular}


TABLE 1 (Continued)

\begin{tabular}{|c|c|c|c|c|}
\hline Time & Ivermectin (mg/L) & Live parasites & Dead parasites & $\mathrm{EC}_{50}$ \\
\hline \multirow[t]{9}{*}{$24 \mathrm{hr}$} & 1,000 & 0 & 0 & \multirow[t]{9}{*}{2,900} \\
\hline & 1,500 & 28 & $0.7 \pm 1.1$ & \\
\hline & 2,000 & 26 & $1.3 \pm 0.6$ & \\
\hline & 2,500 & 27 & $1.0 \pm 1.0$ & \\
\hline & 3,000 & 13 & $5.7 \pm 0.6$ & \\
\hline & 3,500 & 8 & $7.3 \pm 0.6$ & \\
\hline & 4,000 & 7 & $7.7 \pm 4.0$ & \\
\hline & 4,500 & 0 & $10.0 \pm 0$ & \\
\hline & 5,000 & 0 & $10.0 \pm 0$ & \\
\hline Time & Levamisole (mg/L) & Live parasites & Dead parasites & $\mathrm{EC}_{50}$ \\
\hline \multirow[t]{9}{*}{$6 \mathrm{hr}$} & 50 & 30 & 0 & \multirow[t]{9}{*}{-} \\
\hline & 100 & 19 & $3.7 \pm 1.1$ & \\
\hline & 150 & 25 & $1.7 \pm 0.6$ & \\
\hline & 200 & 19 & $3.7 \pm 1.5$ & \\
\hline & 250 & 20 & $3.3 \pm 1.5$ & \\
\hline & 300 & 18 & $4.0 \pm 1.0$ & \\
\hline & 350 & 11 & $6.3 \pm 1.5$ & \\
\hline & 400 & 8 & $7.3 \pm 0.6$ & \\
\hline & 450 & 7 & $7.7 \pm 2.1$ & \\
\hline \multirow[t]{9}{*}{$24 \mathrm{hr}$} & 50 & 20 & $3.3 \pm 1.5$ & \multirow[t]{9}{*}{73.3} \\
\hline & 100 & 9 & $7.0 \pm 1.0$ & \\
\hline & 150 & 11 & $6.3 \pm 1.1$ & \\
\hline & 200 & 11 & $6.3 \pm 1.1$ & \\
\hline & 250 & 9 & $7.0 \pm 1.0$ & \\
\hline & 300 & 0 & $10.0 \pm 0$ & \\
\hline & 350 & 0 & $10.0 \pm 0$ & \\
\hline & 400 & 0 & $10.0 \pm 0$ & \\
\hline & 450 & 0 & $10.0 \pm 0$ & \\
\hline Time & Praziquantel (mg/L) & Live parasites & Dead parasites & $\mathrm{EC}_{50}$ \\
\hline \multirow[t]{9}{*}{$6 \mathrm{hr}$} & 750 & 30 & 0 & \multirow[t]{9}{*}{-} \\
\hline & 1,000 & 30 & 0 & \\
\hline & 1,250 & 30 & 0 & \\
\hline & 1,500 & 30 & 0 & \\
\hline & 1,750 & 30 & 0 & \\
\hline & 2,000 & 30 & 0 & \\
\hline & 2,250 & 29 & $0.3 \pm 0.6$ & \\
\hline & 2,500 & 14 & $5.3 \pm 0.6$ & \\
\hline & 2,750 & 0 & $10.0 \pm 0$ & \\
\hline
\end{tabular}


TABLE 1 (Continued)

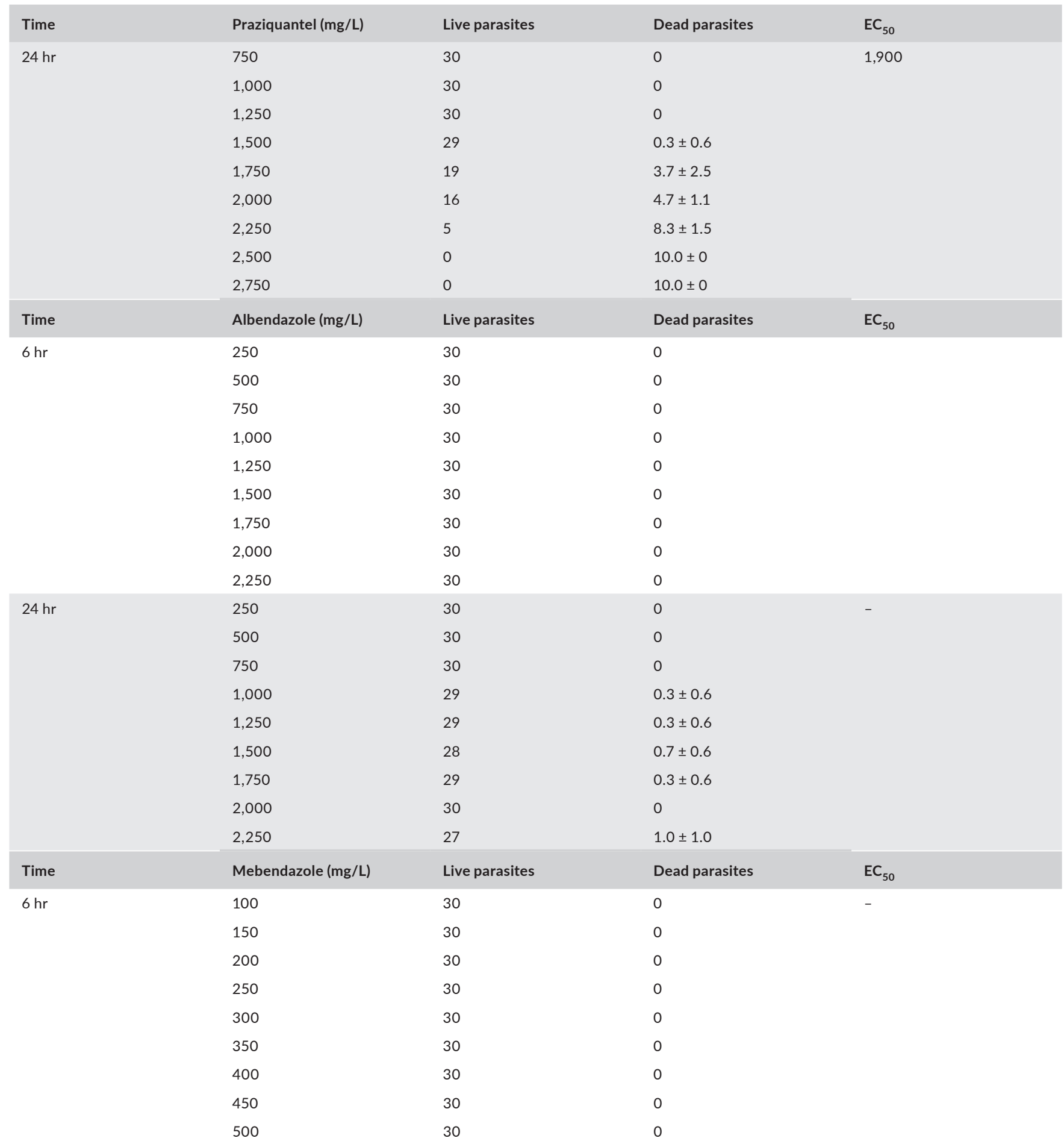


TABLE 1 (Continued)

\begin{tabular}{|c|c|c|c|c|}
\hline Time & Mebendazole (mg/L) & Live parasites & Dead parasites & $\mathrm{EC}_{50}$ \\
\hline \multirow[t]{9}{*}{$24 \mathrm{hr}$} & 100 & 30 & 0 & - \\
\hline & 150 & 29 & $0.3 \pm 0.6$ & \\
\hline & 200 & 30 & 0 & \\
\hline & 250 & 29 & $0.3 \pm 0.6$ & \\
\hline & 300 & 28 & $0.7 \pm 1.1$ & \\
\hline & 350 & 30 & 0 & \\
\hline & 400 & 30 & 0 & \\
\hline & 450 & 29 & $0.3 \pm 0.6$ & \\
\hline & 500 & 29 & $0.3 \pm 0.6$ & \\
\hline Time & Fenbendazole (mg/L) & Live parasites & Dead parasites & \\
\hline \multirow[t]{9}{*}{$6 \mathrm{hr}$} & 0.2 & 30 & 0 & \\
\hline & 0.3 & 30 & 0 & \\
\hline & 0.4 & 30 & 0 & \\
\hline & 0.5 & 30 & 0 & \\
\hline & 0.6 & 30 & 0 & \\
\hline & 0.7 & 30 & 0 & \\
\hline & 0.8 & 30 & 0 & \\
\hline & 0.9 & 30 & 0 & \\
\hline & 1.0 & 30 & 0 & \\
\hline \multirow[t]{9}{*}{$24 \mathrm{hr}$} & 0.2 & 30 & 0 & \\
\hline & 0.3 & 30 & 0 & \\
\hline & 0.4 & 30 & 0 & \\
\hline & 0.5 & 30 & 0 & \\
\hline & 0.6 & 30 & 0 & \\
\hline & 0.7 & 30 & 0 & \\
\hline & 0.8 & 30 & 0 & \\
\hline & 0.9 & 30 & 0 & \\
\hline & 1.0 & 30 & 0 & \\
\hline Time & Loperamide (mg/L) & Live parasites & Dead parasites & \\
\hline \multirow[t]{9}{*}{$6 \mathrm{hr}$} & 20 & 30 & 0 & \\
\hline & 40 & 30 & 0 & \\
\hline & 60 & 30 & 0 & \\
\hline & 80 & 30 & 0 & \\
\hline & 100 & 30 & 0 & \\
\hline & 120 & 30 & 0 & \\
\hline & 140 & 30 & 0 & \\
\hline & 160 & 30 & 0 & \\
\hline & 180 & 30 & 0 & \\
\hline \multirow[t]{9}{*}{$24 \mathrm{hr}$} & 20 & 29 & $0.3 \pm 0.6$ & \\
\hline & 40 & 26 & $1.3 \pm 1.1$ & \\
\hline & 60 & 29 & $0.3 \pm 0.6$ & \\
\hline & 80 & 30 & 0 & \\
\hline & 100 & 30 & 0 & \\
\hline & 120 & 29 & $0.3 \pm 0.6$ & \\
\hline & 140 & 29 & $0.3 \pm 0.6$ & \\
\hline & 160 & 28 & $0.7 \pm 1.1$ & \\
\hline & 180 & 26 & $1.3 \pm 1.5$ & \\
\hline
\end{tabular}


Emamectin benzoate

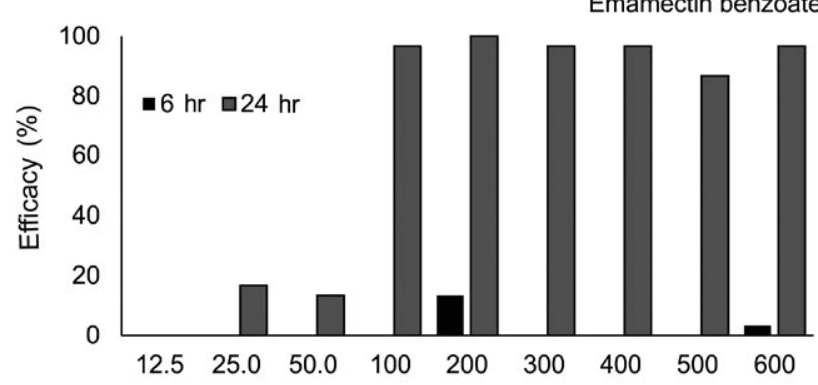

Ivermectin

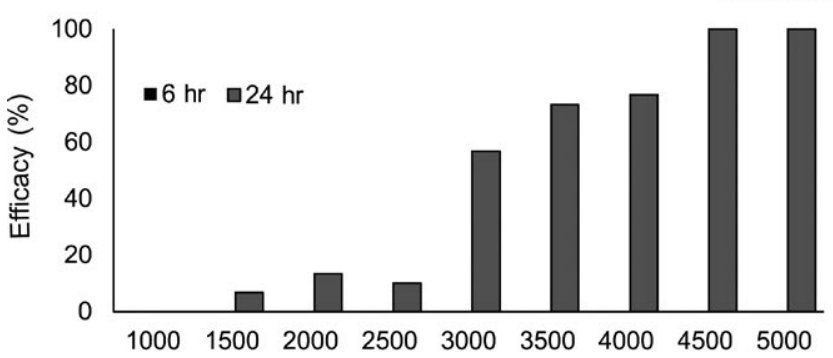

Levamisole

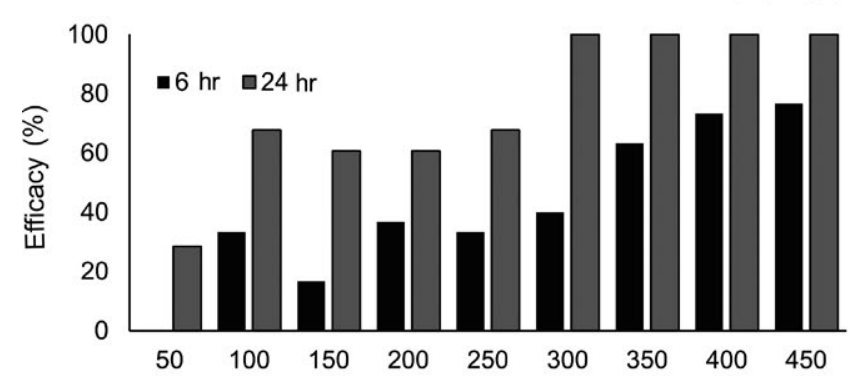

Praziquantel

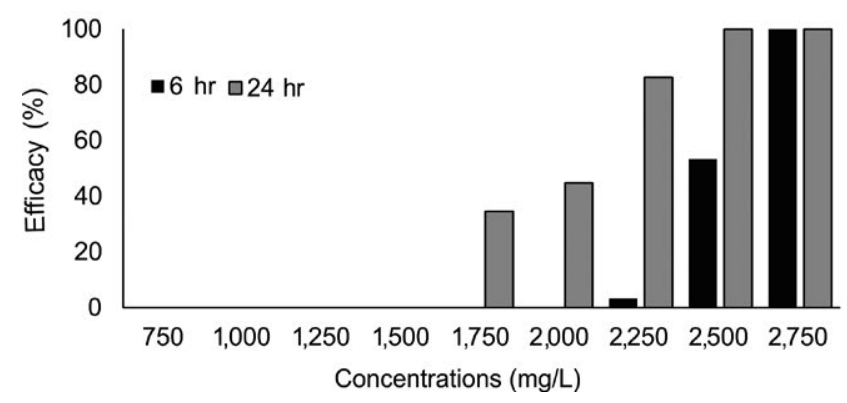

FIGURE 1 Efficacy of the anthelminthics against Neoechinorhynchus buttnerae of Colossoma macropomum in 6 and $24 \mathrm{hr}$ of exposure

For these trials in vitro, we used eight anthelmintic drugs and forty juveniles of $C$. macropomum $(100.0 \pm 20.0 \mathrm{~g})$ obtained from a commercial fish farm in Manaus, Amazonas state (Brazil). All the fish had the intestine naturally infected by $N$. buttnerae. Parasites obtained were stored in Eagle's minimal essential at room temperature $\left(25.0 \pm 1.0^{\circ} \mathrm{C}\right)$ in combination with different concentrations of albendazole, levamisole, mebendazole, fenbendazole, emamectin benzoate, ivermectin, loperamide and praziquantel. The efficacy of concentrations of each anthelminthic drug was tested using three replicates per treatment and 10 adults of $N$. buttnerae in each replicate. The endoparasites were considered dead when had totally lost mobility. The effective concentration ( $\mathrm{EC}_{50-24 \mathrm{hr}}$ ) and $95 \%$ confidence interval were determined for each anthelminthic drug, using the software Trimmed Spearman-Karber method (Hamilton, Russo, \& Thurston, 1977).

Only levamisole, praziquantel, emamectin benzoate and ivermectin caused mortality of $N$. buttnerae. The $\mathrm{EC}_{50}$ was also determined for the anthelminthic drugs (Table 1). For levamisole, the $95 \%$ confidence interval was 49.3-108.8 mg/L; for praziquantel, 1,800$2,000 \mathrm{mg} / \mathrm{L}$; for emamectin benzoate, $52.7-72.4 \mathrm{mg} / \mathrm{L}$ and for ivermectin, 2,700-3,100 mg/L. However, the effects of emamectin benzoate and levamisole were not dependent on concentration. Praziquantel also presented high efficacy in vitro against $N$. rutili and E. truttae in O. mykiss (Taraschewski et al., 1990). Low concentrations of ivermectin in the diet of Danio rerio Hamilton, 1822 had little efficacy (24\%) against the nematodes Pseudocapillaria tomentosa Dujardin, 1843, while emamectin benzoate had $90 \%$ efficacy (Collymore et al., 2014). Despite this positive effect of emamectin benzoate, its use is restricted for agriculture in most of the states in Brazil, thus limiting its use in aquaculture, which has not legal approbation.

The concentrations of emamectin benzoate and ivermectin that were used showed high in vitro efficacy against $N$. buttnerae of C. macropomum after $24 \mathrm{hr}$ of exposure, but the efficacy of praziquantel and levamisole started at $6 \mathrm{hr}$ of in vitro exposure (Figure 1). Levamisole showed low efficacy against $N$. buttnerae at $6 \mathrm{hr}$ of exposure. Taraschewski et al. (1990) reported that levamisole presented efficacy against N. rutili and E. truttae after $1 \mathrm{hr}$ of exposure. No concentration of albendazole, fenbendazole, mebendazole or loperamide showed in vitro efficacy against $N$. buttnerae of $C$. macropomum, since they are poorly soluble in water, resulting therefore in variable and incomplete bioavailability (Ghanbarzadeh et al., 2016; Ibrahim \& Al-Anazi, 2013; Pacheco et al., 2018; Romero, Navarro, Sanchez, \& Valero, 2014; Taraschewski et al., 1990). Similar inefficacy of albendazole, fenbendazole and mebendazole has also been reported in relation to species of acanthocephalans, nematodes, monogeneans and trematodes parasitizing different fish species (Reimschuessel, Gieseker, \& Poynton, 2011; Romero et al., 2014; Taraschewski et al., 1990; Zhang et al., 2014).

Loperamide did not show efficacy against N. buttnerae in C. macropomum in the present study, contrary to our expectations. However, loperamide was effective against N. rutili and E. truttae, because it causes contractions and necrosis in acanthocephalans, along with mitochondrial swelling that may result in expulsion of the cytoplasm out of the tegument pores (Taraschewski et al., 1990).

The acanthocephalan N. buttnerae of C. macropomum presented slow movements only after $6 \mathrm{hr}$ of exposure to the highest concentrations of emamectin benzoate, ivermectin and praziquantel. Reimschuessel et al. (2011) also reported that there was a tardy response after in vitro exposure of Acolpenteron ureteroecetes Fischthal \& Allison, 1940 to emamectin benzoate and ivermectin. However, Zhang et al. (2014) reported an immediate change in the movement 
of Dactylogyrus vastator Nybelin, 1924 after exposure to praziquantel. Praziquantel has a mechanism of action based on depolarization of the tegument of helminth parasites, thus leading to entry of calcium into the cells, hence causing immobilization, spasmodic contractions and paralysis (Hardy-Smith et al., 2012; Sitja-Bobadilla, Felipe, \& Alvarez-Pellitero, 2006; Thomas \& Timson, 2018; Williams, Ernst, Chambers, \& Whittington, 2007).

To conclude, our results showed that $100 \mathrm{mg} / \mathrm{L}$ of emamectin benzoate, $300 \mathrm{mg} / \mathrm{L}$ of levamisole, $4,500 \mathrm{mg} / \mathrm{L}$ of ivermectin and $2,500 \mathrm{mg} / \mathrm{L}$ of praziquantel had the highest efficacy against $\mathrm{N}$. buttnerae. These concentrations can be recommended for use in the diet of $C$ macropomum after previous evaluation of the toxicity. Therefore, these first results represent a great step forward regarding integrated management for controlling $N$. buttnerae in farmed C. macropomum.

\section{ACKNOWLEDGEMENTS}

The authors also thank the Conselho Nacional de Desenvolvimento Científico e Tecnológico (CNPq, Brazil) for the productivity research grant awarded to M. Tavares-Dias (\# 303013/2015-0) and Acanto project from Embrapa.

\section{CONFLICT OF INTEREST}

The authors declare no conflict of interest.

\section{ETHICAL DISCLOSURES}

This study was developed in accordance with the principles adopted by the Brazilian College of Animal Experimentation (COBEA), and authorization from Ethics Committee in the Use of Animal of the Embrapa Amazônia Ocidental ( $\left.N^{\circ} 02 / 2017\right)$ was carried out.

\section{ORCID}

Marcos Tavares-Dias (iD https://orcid.org/0000-0002-8376-1846

\section{REFERENCES}

Collymore, C., Watral, V., White, J. R., Colvin, M. E., Rasmussen, S., Tolwani, R. J., \& Kent, M. L. (2014). Tolerance and efficacy of emamectin benzoate and ivermectin for the treatment of Pseudocapillaria tomentosa in laboratory Zebrafish (Danio rerio). Zebrafish, 11, 490497. https://doi.org/10.1089/zeb.2014.1021

Ghanbarzadeh, S., Khalili, A., Jouyban, A., Emami, S., Javadzadeh, Y., Solhi, M., \& Hamishehkar, H. (2016). Dramatic improvement in dissolution rate of albendazole by a simple, one-step, industrially scalable technique. Research in Pharmaceutical Sciences, 11(6), 435-444. https://doi.org/10.4103/1735-5362.194868

Hamilton, M. A., Russo, R. C., \& Thurston, R. V. (1977). Trimmed spearman-Karber method for estimating median lethal concentrations in toxicity bioassays. Environmental Science \& Technology, 11, 714-719. Correction. 12: 417. https://doi.org/10.1021/es60130a004
Hardy-Smith, P., Ellis, D., Humphrey, J., Evans, M., Evans, D., Rough, K., .. Nowak, B. (2012). In vitro and in vivo efficacy of anthelmintic compounds against blood fluke (Cardicola forsteri). Aquaculture, 334-337, 39-44. https://doi.org/10.1016/j.aquaculture.2011.12.037

Ibrahim, M. A., \& Al-Anazi, F. K. (2013). Enhancement of the dissolution of albendazole from pellets using MTR technique. Saudi Pharmaceutical Journal, 21, 215-223. https://doi.org/10.1016/j.jsps.2012.03.001

Jerônimo, G. T., Pádua, S. B., Belo, M. A. A., Chagas, E. C., Taboga, S. R., Maciel, P. O., \& Martins, M. L. (2017). Neoechinorhynchus buttnerae (Acanthocephala) infection in farmed Colossoma macropomum: a pathological approach. Aquaculture, 469, 124-127. https://doi. org/10.1016/j.aquaculture.2016.11.027

Lourenço, F. S., Morey, G. A. M., Pereira, J. N., \& Malta, J. C. O. (2017). Ocorrência de Neoechinorhynchus (Neoechinorhynchus) buttnerae Golvan, 1956 (Acanthocephala: Neoechinorhynchidae) em Colossoma macropomum (Cuvier, 1818) Characiformes: Serrasalmidae) provenientes de uma piscicultura da Amazônia brasileira. Folia Amazónica, 26(1), 1-8. https://doi.org/10.24841/ fa.v26i1.41

Lourenço, F. S., Morey, G. A. M., Pereira, J. N., \& Malta, J. C. O. (2018). The development of Neoechinorhynchus buttnerae (Eoacanthocephala: Neoechinorhynchidae) in its intermediate host Cypridopsis vidua in Brazil. Acta Parasitologica, 63(2), 354-359. https://doi.org/10.1515/ ap-2018-0040

Matos, L. V., Oliveira, M. I. B., Gomes, A. L. S., \& Silva, G. S. (2017). Morphological and histochemical changes associated with massive infection by Neoechinorhynchus buttnerae (Acanthocephala: Neoechinorhynchidae) in the farmed freshwater fish Colossoma macropomum Cuvier, 1818 from the Amazon State, Brazil. Parasitology Research, 116, 1029-1037. https://doi.org/10.1007/ s00436-017-5384-3

Pacheco, P. A., Rodrigues, L. N. C., Ferreira, J. F. S., Gomes, A. C. P., Veríssimo, C. J., Louvandini, H., ... Katiki, L. M. (2018). Inclusion complex and nanoclusters of cyclodextrin to increase the solubility and efficacy of albendazole. Parasitology Research, 117(3), 705-712. https://doi.org/10.1007/s00436-017-5740-3

Reimschuessel, R., Gieseker, C., \& Poynton, S. (2011). In vitro effect of seven antiparasitic on Acolpenteron ureteroecetes (Dactylogyridae) from largemouth bass Micropterus salmoides (Centrarchidae). Diseases of Aquatic Organisms, 94, 59-72. https://doi.org/10.3354/ dao02303

Romero, M. C., Navarro, M. C., Sanchez, J. M., \& Valero, A. (2014). Peppermint (Mentha piperita) and albendazole against anisakiasis in an animal model. Tropical Medicine and International Health, 19, 14301436. https://doi.org/10.1111/tmi.12399

Shinn, A. P., \& Bron, J. E. (2012). Considerations in the use of antiparasitic drugs in aquaculture. In B. A. Austin (Ed.), Infectious disease in aquaculture prevention and control (pp. 190-217). Cambridge, UK: Woodhead Publishing Limited. https://doi. org/10.1533/9780857095732.2.190

Silva-Gomes, A. L., Coelho-Filho, J. G., Viana-Silva, W., BragaOliveira, M. I., Bernardino, G., \& Costa, J. I. (2017). The impact of Neoechinorhynchus buttnerae (Golvan, 1956) (Eoacanthocephala: Neochinorhynchidae) outbreaks on productive and economic performance of the tambaqui Colossoma macropomum (Cuvier, 1818), reared in ponds. Latin American Journal of Aquatic Research, 45(2), 496-500. https://doi.org/10.3856/vol45-issue2-fulltext-25

Sitja-Bobadilla, A., Felipe, M. C., \& Alvarez-Pellitero, P. (2006). In vivo and in vitro treatments against Sparicotyle chrysophrii (Monogenea: Microcotylidae) parasitizing the gills of gilthead sea bream (Sparus aurata L.). Aquaculture, 261(3), 856-864. https://doi.org/10.1016/j. aquaculture.2006.09.012

Taraschewski, H., Mehlhorn, H., \& Raether, W. (1990). Loperamid, an efficacious drug against fish-pathogenic acanthocephalans. Parasitology Research, 76, 619-623. https://doi.org/10.1007/BF00932573 
Thomas, C. M., \& Timson, D. J. (2018). The mechanism of action of praziquantel: six hypotheses. Current Topics in Medicinal Chemistry, 18, 1575-1584. https://doi.org/10.2174/15680266186661810291432 14

Williams, R. E., Ernst, I., Chambers, C. B., \& Whittington, I. D. (2007). Efficacy of orally administered praziquantel against Zeuxapta seriolae and Benedenia seriolae (Monogenea) in yellowtail kingfish Seriola lalandi. Diseases of Aquatic Organisms, 77, 199-205. https://doi. org/10.3354/dao01824

Zhang, X. P., Li, W. X., Ai, T. S., Zou, H., Wu, S. G., \& Wang, G. T. (2014). The efficacy of four common anthelmintic drugs and traditional Chinese medicinal plant extracts to control Dactylogyrus vasta tor (Monogenea). Aquaculture, 420-421, 302-307. https://doi. org/10.1016/j.aquaculture.2013.09.022

Zuskova, E., Piackova, V., Machova, J., Chupani, L., Steinbach, C., Stara, A., \& Velisek, J. (2018). Efficacy and toxicity of praziquantel in helminth-infected barbel (Barbus barbus L.). Journal of Fish Diseases, 41(4), 643-649. https://doi.org/10.1111/jfd.12764

How to cite this article: Oliveira LCD, Majolo C, Brandão FR, et al. Avermectins, praziquantel and levamisole have in vitro efficacy against Neoechinorhynchus buttnerae (Neoechinorhynchidae) in Colossoma macropomum: A Serrasalmidae from the Amazon. J Fish Dis. 2019;42:765-772. https://doi.org/10.1111/jfd.12980 